\title{
Expert opinion on the technical condition of purlins and girders in the roof of a slag storage hall
}

\author{
Tadeusz Czarniawski ${ }^{1}$
}

\begin{abstract}
:
The intensive development of industrial construction imposes the necessity to apply new technological and construction solutions, taking into account changes in legal regulations. At present we are in a situation where a significant part of buildings and structures was designed and constructed during the validity period of standards and regulations which are currently outdated. This situation forces owners and users of existing facilities to assess them in terms of compliance with currently valid Eurocodes.
\end{abstract}

\section{KEYWORDS:}

metal structures; Eurocodes; industrial hall; strength calculations

\section{Introduction}

The subject of the article is the trough reloading hall located on the premises of ArcelorMittal Poland S.A. in Dąbrowa Górnicza. The main aim of the analysis was to assess the technical condition of the roof slats and girders of the hall, and to strengthen the existing structure.

The scope of this analysis includes: Photographic inventory of damage to the hall roof structure elements, description of the technical condition of the roof structure elements, strength assessment of the structure based on the current standards and strengthening of the structure, if required by strength analysis and design of damaged structure elements.

\section{Description of the hall structure}

The crushing plant was erected in 1974 on a rectangular plan with dimensions of $144 \times 30 \mathrm{~m}$, as a single-bay hall in a system of two columns rigidly fixed on foundations with a roof truss based on articulated non-displacement on lattice girders based on columns. The hall is a freestanding facility, a gas flyover runs along the west side of the hall (Figs. 1-5).

The steel columns of the hall are spaced every $12.0 \mathrm{~m}$, in the crane section there are twobranch bars, and in the upper part they are single-branch. The trusses were made as trapezoidal trusses, while the roof purlins were made as flat trusses. Roof trusses are spaced every $12.0 \mathrm{~m}$, and roof purlins every $3.0 \mathrm{~m}$. It has reinforced concrete block foundations. The wall cladding is made of trapezoidal sheets. The hall serves as a slag storage and reloading hall.

Hall parameters:

Building area: $\quad 4320,0 \mathrm{~m}^{2}$

Volume $\quad 117100,0 \mathrm{~m}^{3}$

Hall height: $\quad 24,0 \mathrm{~m} \quad$ (flat part of the roof)

$36,0 \mathrm{~m} \quad$ (field raised - additional lighting)

${ }^{1}$ Czestochowa University of Technology, Faculty of Civil Engineering, ul. Akademicka 3, 42-218 Czestochowa, e-mail: tadeusz.czarniawski@pcz.pl, orcid id: 0000-0003-3460-4948 


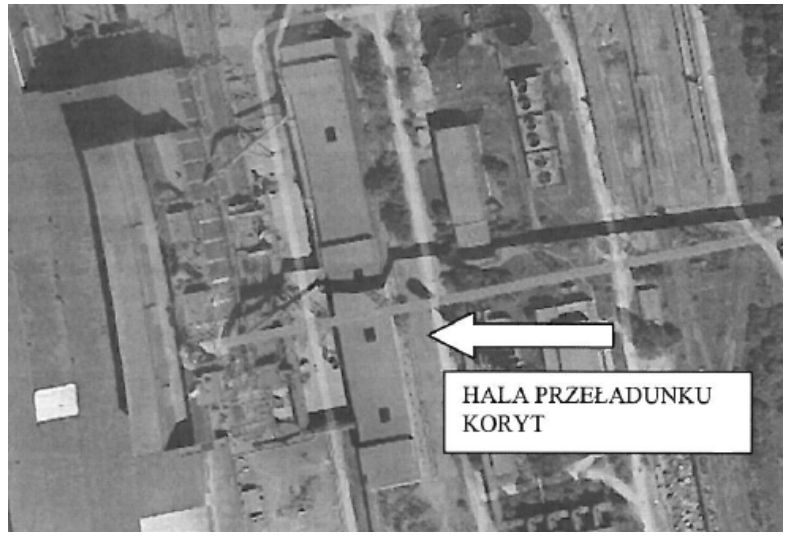

Fig. 1. Location of the hall

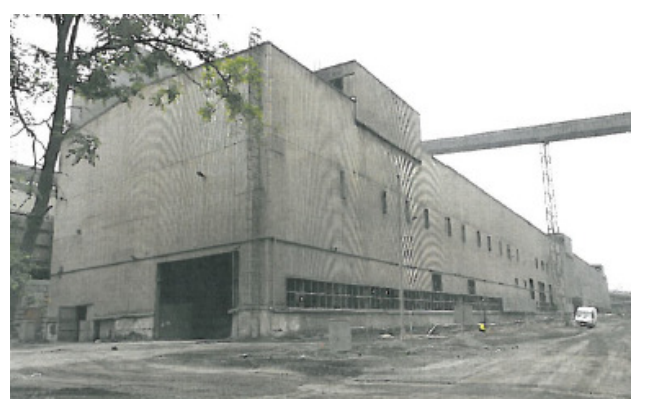

Fig. 2. View of the southern and eastern walls

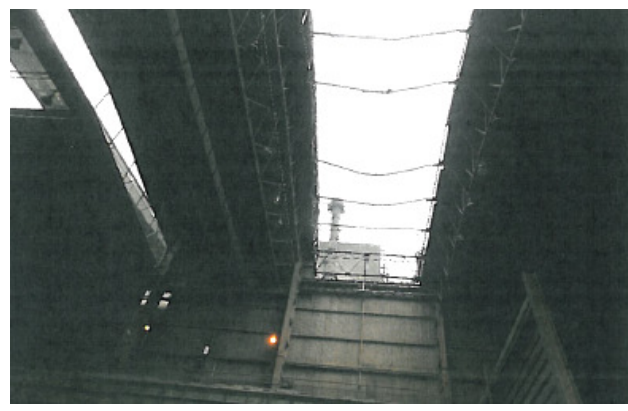

Fig. 4. View of the roof structure - trusses

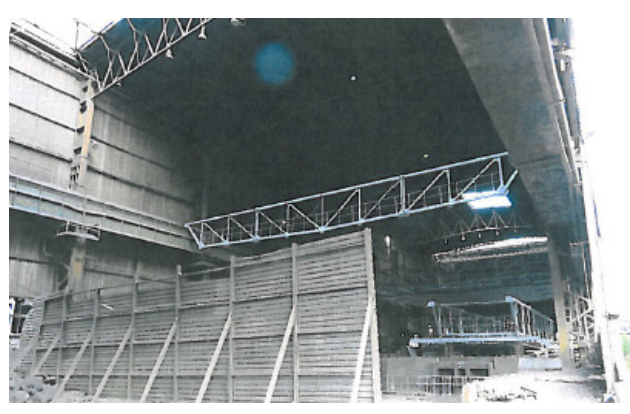

Fig. 3. View of the roof structure - trusses

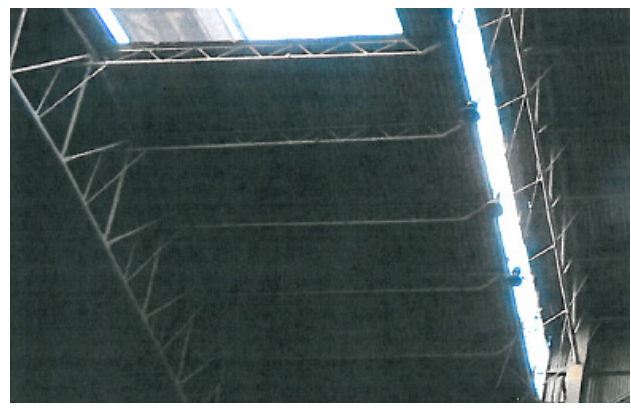

Fig. 5. View of the roof structure - purlins

The main load-bearing element of the roof structure is a steel truss with a span of $30.0 \mathrm{~m}$. Constant height of the girders is $3.0 \mathrm{~m}$, made with a slope in two directions (Fig. 6). Roof slope $10 \%$.

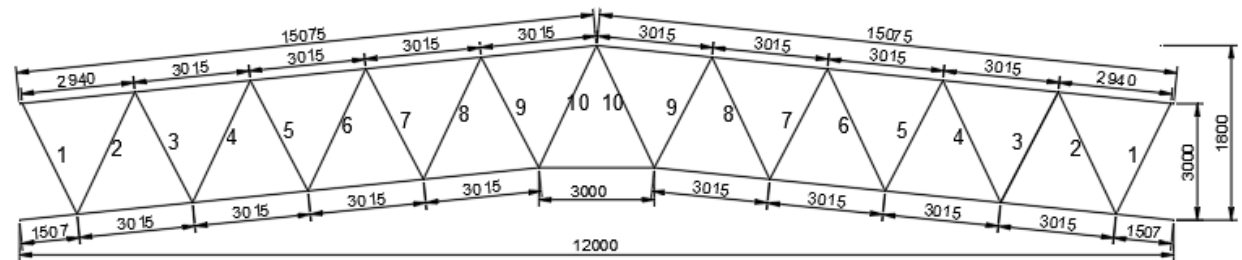

Fig. 6. Static diagram of the girders W15, W16, W17, W18 
Table 1 summarizes the adopted truss sections based on the archival documentation.

Table 1

\begin{tabular}{|l|l|l|}
\hline Element & W15 and W16 & W17 and W18 \\
\hline Bottom belt & F159x6.3 + F159x8 & F159x8 + F159x12 \\
\hline Top belt & F193.7x6 + F193.7x11 & F193.7x8 + F193.7x11 \\
\hline Cross brace 1 & F108.0x5,0 & F108.0x5.0 \\
\hline Cross brace 2 & F139.7x5,0 & F139.7x8.0 \\
\hline Cross brace 3 & F108.0x8,0 & F108.0x8.0 \\
\hline Cross brace 4 & F114.3x8,0 & F114.3x8 \\
\hline Cross brace 5 & F88.9x3,5 & F95.0x4.0 \\
\hline Cross brace 6 & F108.0x4,5 & F108.0x8.0 \\
\hline Cross brace 7 & F88.9x3,5 & F95.0x4.0 \\
\hline Cross brace 8 & F108.0x4,0 & F108.0x8.0 \\
\hline Cross brace 9 & F88.9x3,5 & F95.0x4.0 \\
\hline Cross brace 10 & F88.9x4,0 & F95.0x4.0 \\
\hline
\end{tabular}

The purlins were made as trusses with the following spans: $12.0 \mathrm{~m} ; 10.5 \mathrm{~m} ; 9.0 \mathrm{~m}$ :

- $12.0 \mathrm{~m}$ long purlins: the upper flange is made as a T profile, where the flange $-8 \times 200 \mathrm{~m}$ sheet, web - 8x120 mm sheet, diagonals - F22 mm rod, bottom flange - F89x8 mm steel pipe.

- $10.5 \mathrm{~m}$ long purlins: the upper flange is made as a T profile, where the flange - sheet $6 \times 160 \mathrm{~m}$, web - sheet $6 \times 100 \mathrm{~mm}$, diagonals - F14 and $16 \mathrm{~mm}$ rod, bottom flange - steel pipe F89x8 mm.

- $9.0 \mathrm{~m}$ long purlins: the upper flange is made as a T profile, where the flange $-6 \times 160 \mathrm{~m}$ sheet, web - 6x100 mm sheet, diagonals - F22 mm bar, bottom flange - T60x7 T-bar.

Table 2 summarizes the adopted purlin cross-sections based on the archival documentation

Table 2

\begin{tabular}{|l|l|l|l|l|l|}
\hline Element & $\mathrm{L}$ & $\mathrm{h}$ & Top Belt & Bottom Belt & Diagonals \\
\hline P34, P35, P36 & $9.0 \mathrm{~m}$ & $0,600 \mathrm{~m}$ & $\perp 160 \mathrm{x} 6 ; \perp 100 \mathrm{x} 6$ & $\perp 160 \mathrm{x} 7$ & $2 \mathrm{xF} 16 ; 2 \mathrm{xF} 14$ \\
\hline P33 & $9.9 \mathrm{~m}$ & $0,600 \mathrm{~m}$ & $\perp 160 \mathrm{x} 6 ; \perp 100 \mathrm{x} 6$ & $\perp 160 \mathrm{x} 7$ & $2 \mathrm{xF} 16 ; 2 \times \mathrm{xF} 14$ \\
\hline P5, P6, P8 & $15.0 \mathrm{~m}$ & $0,750 \mathrm{~m}$ & $\perp 220 \mathrm{x} 10 ; \perp 150 \mathrm{x} 8$ & $\perp 95 \mathrm{x} 7$ & $2 \mathrm{xF} 16 ; 2 \mathrm{xF} 14$ \\
\hline P20 & $15.0 \mathrm{~m}$ & $1,200 \mathrm{~m}$ & $\perp 200 \mathrm{x} 8 ; \perp 120 \mathrm{x} 8$ & $\perp 89 \mathrm{x} 8$ & $1 \mathrm{xF} 24 ; 1 \mathrm{xF} 22$ \\
\hline P31, P32, P33 & $12.0 \mathrm{~m}$ & $0,750 \mathrm{~m}$ & $\perp 160 \mathrm{x} 6 ; \perp 100 \mathrm{x} 6$ & $\perp 95 \mathrm{x} 7$ & $2 \times \mathrm{xF} 16 ;$ \\
\hline P39 & $12.0 \mathrm{~m}$ & $1,200 \mathrm{~m}$ & $\perp 160 \mathrm{x} 6 ; \perp 100 \mathrm{x} 6$ & $\perp 89 \mathrm{x} 8$ & $2 \mathrm{xF} 16 ; 2 \mathrm{~F} 14$ \\
\hline
\end{tabular}

\section{Inventory of damage to the elements of the roof structure}

During the inspection of the hall roof, a number of defects and damages to the hall structure elements were found. In general, the entirety of the damage to the roof structure of the hall can be divided into two main groups:

- damage to the load-bearing elements of the roof structure,

- damage to the hall roof.

The main damage is to the roof supporting structure and can be divided into:

- deformation of the roof supporting structure elements,

- corrosion of the load-bearing elements of the roof structure,

- heavy wear of paint coatings.

\section{Deformation of the elements of the roof supporting structure}

The steel roof structure is in a varied technical condition. The significant problems include:

- clear and permanent buckling of parts of the truss purlins,

- too little support of the truss lower flange on the gusset plate of the column,

- damage to the housing structure of the raised hall. 


\section{Analysis of static and strength calculations}

Tangential-strength calculations were performed in order to check the boundary conditions of the structure in question in the existing state. The calculations were made using RAMA 2D3D. The load-bearing capacity of the compression and tension elements were checked in accordance with the assumptions of PN-EN 1993-1-1. It should be noted that the structure was designed in 1973. As is known, the characteristic loads increased significantly compared to 1970 due to changes in load standards. The loads were determined on the basis of information provided in the existing technical documentation and on the basis of PN-EN 1991-1-1. The values of the characteristic snow load on the ground were adopted according to the annex to the European standard PN-EN 1991-1-3 for the location in Dąbrowa Górnicza. Wind loads were determined on the basis of PN-EN-1991-1-1.

Due to the increase in characteristic loads, on the basis of calculations, the permissible stresses in some elements of the roof structure were exceeded.

In the W15, W16, W17 and W18 roof girders, the exceedance occurred in diagonals no. 2, 4, 5 and 6 (Fig. 7).

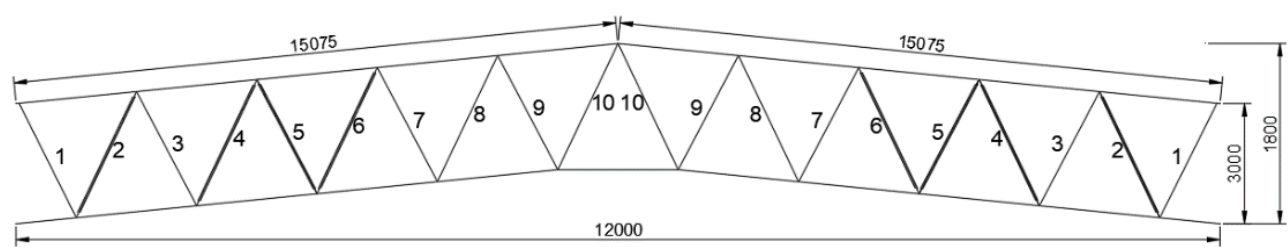

Fig. 7. List of roof girder bars with exceeded load

In the purlins, the diagonal load was exceeded (Fig. 8).

- Purlin P1, P3

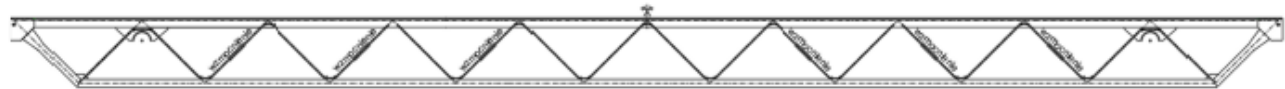

- Purlin P19

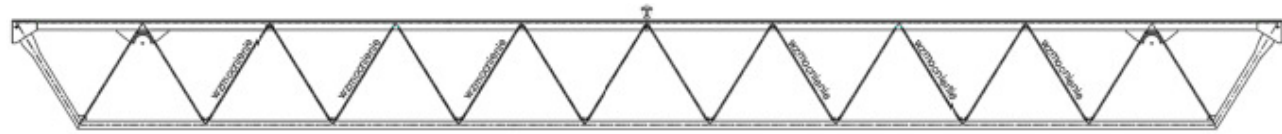

- Purlin P21, P22, P23

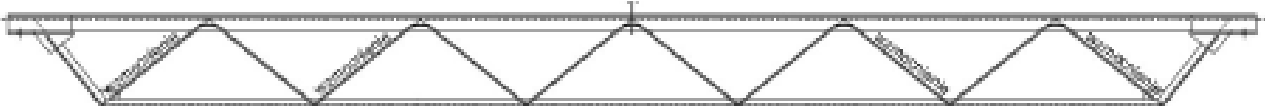

- P33, P34, P35

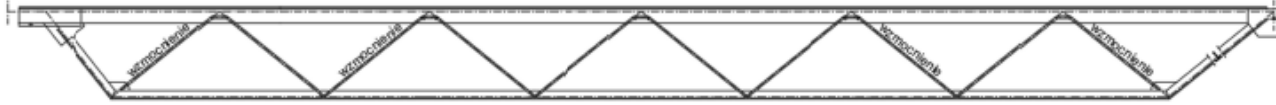

- P30, P31

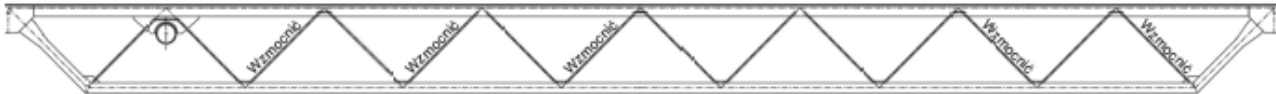

- P39

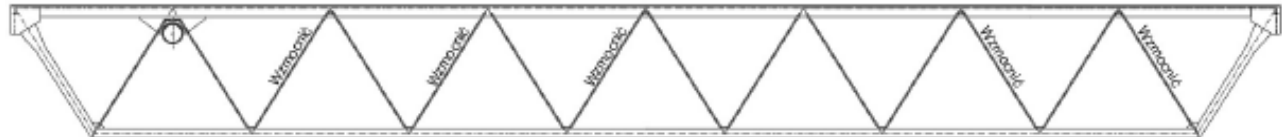

Fig. 8. List of roof girder bars with exceeded load 


\section{Conclusions and recommendations}

- Reinforcement of the girders W15, W16, W17, W18

- The load capacity conditions for the upper and lower flanges have not been exhausted.

- The load-bearing capacity conditions for diagonal no. 2, no. 4, no. 5 and no. 6 were exceeded.

- Due to the fact that the reinforcement of the roof structure is to be made without dismantling the structure, overlays stiffening the diagonals were used.

- The overlays are designed according to the changing diameters of the diagonal, they are to be made of steel pipes with internal diameters equal to the external diameters of the diagonal and the wall thickness of $6 \mathrm{~mm}$. The overlays increase the load capacity of the diagonal by increasing their flexural stiffness. The covers are fixed with M10 screws, class 8.8.

For the diagonal no. 1 and the W16 girder, stiffening solutions are presented in Figure 9.

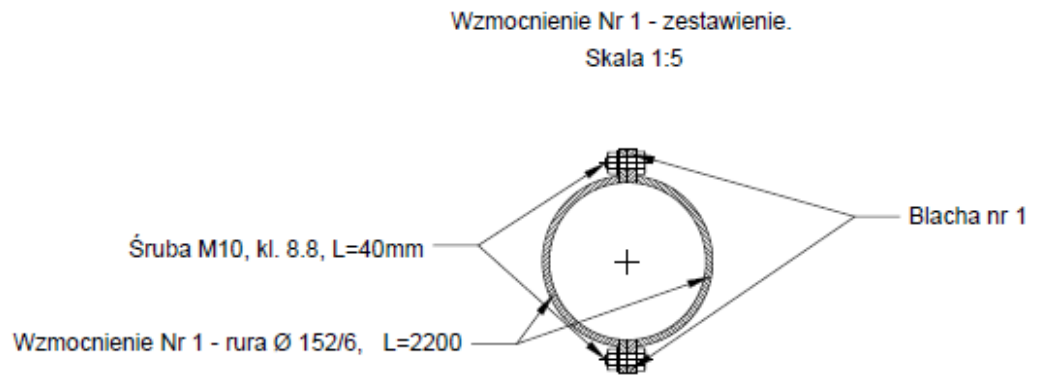

Fig. 9. Strengthening the cross-brace of the roof girders

The remaining reinforcements were built in a similar way.
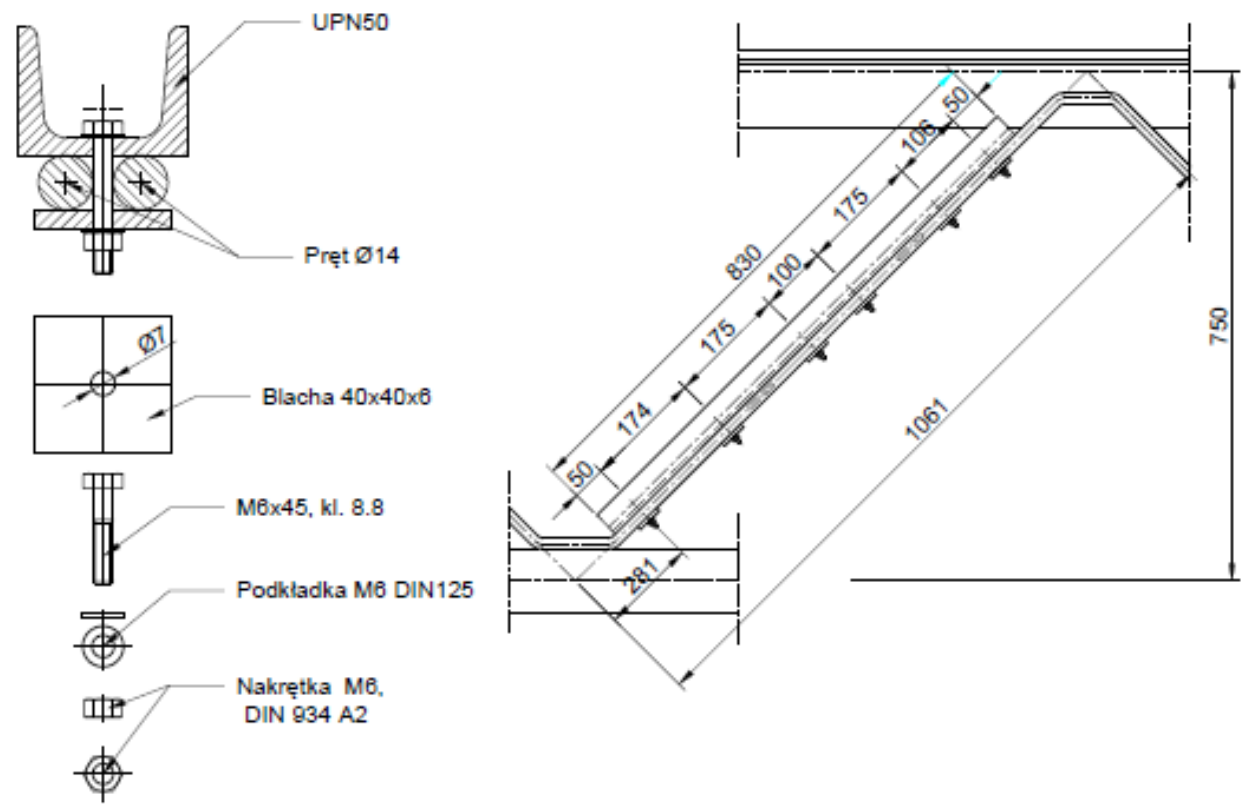

Fig. 10. Strengthening the cross-brace of the lattice purlins

- Reinforcement of purlins

- The load capacity conditions for the upper and lower flanges have not been exhausted.

- The load-bearing capacity conditions for the supporting diagonal were exceeded. 
- Due to the fact that the reinforcement of the roof structure is to be made without dismantling the structure, an overlay stiffening the diagonals was used.

- The overlay was designed from an UPN channel section, the solution of the diagonal stiffening is shown in Figure 10 (solution for P3 purlins).

The remaining reinforcements were built in the same way, taking into account the diameters and spacing of the diagonal bars.

\section{References}

[1] Kuliński K., Major M., Analiza porównawcza przemieszczeń i naprężeń obliczonych w programach komputerowych wspomagających projektowanie konstrukcji budowlanych, Zeszyty Naukowe Politechniki Częstochowskiej 2014, Budownictwo 20,112-119.

[2] Palacz P., Major M., Analiza porównawcza przemieszczeń ustroju prętowego z użyciem programów ADINA, Autodesk Robot oraz RFEM, Zeszyty Naukowe Politechniki Częstochowskiej 2018, Budownictwo 24, 262-266.

[3] PN-EN 1990:2004, Eurokod 0: Eurokod, Podstawy projektowania konstrukcji.

[4] PN-EN 1991-1-3:2005, Eurokod 1: Oddziaływanie na konstrukcje. Część 1-3: Oddziaływania ogólne. Obciążenie śniegiem.

[5] PN-EN 1991-1-4:2008, Eurokod 1: Oddziaływanie na konstrukcje. Część 1-4: Oddziaływania ogólne. Oddziaływanie wiatru.

[6] PN-EN 1993-1-1:2006, Eurokod 3: Projektowanie konstrukcji stalowych. Część 1-1: Reguły ogólne i reguły dla budynków.

[7] PN-EN 1993-1-5:2008, Eurokod 3: Projektowanie konstrukcji stalowych. Część 1-5: Blachownice

[8] Papiernik T., Ekspertyza stanu technicznego płatwi oraz dźwigarów dachu hali magazynowania i przeładunku żużla, 2018.

\section{Ekspertyza stanu technicznego płatwi i dźwigarów dachu hali magazynowania żużla}

\section{STRESZCZENIE:}

Intensywny rozwój budownictwa przemysłowego narzuca konieczność stosowania nowych rozwiązań technologicznych i konstrukcyjnych, uwzględniając zmiany zachodzące w przepisach prawa. Obecnie znajdujemy sie w sytuacji, gdzie istotna cześć budynków i budowli została zaprojektowana i wykonana w okresie obowiązywania norm i przepisów, które w chwili obecnej są nieaktualne. Sytuacja taka wymusza na właścicielach i użytkownikach istniejących obiektów ich ocenę pod względem zgodności z obecnie obowiązującymi Eurokodami.

\section{SŁOWA KLUCZOWE:}

konstrukcje metalowe; Eurokody; hala przemysłowa; obliczenia wytrzymałościowe 